\title{
The Languages to Sell in Two Commercial Sites in an Indonesian Small Town
}

\author{
Shierlynda Winnindya Riyandi ${ }^{1}$ and Khristianto ${ }^{2}$ \\ ${ }^{1,2}$ Universitas Muhammadiyah Purwokerto, Indonesia \\ (kristian.topz@gmail.com)
}

\begin{abstract}
The primary goals of this research are to determine the language patterns of the signs, characterize the employment of different languages in these patterns, and explain the language situation reflected by the LL signals in the two locations. It applied a mixed method (Cresswell: 2018). The subject of this research includes shop signs, slogans, and also some of the advertising signs displayed in the sites. The signs were then seen from the number of languages displayed and their source. For the analysis, it adopted the view of Scollon and Scollon and ScollonWong (2003). Based on the results of the analysis, the signs can be classified as monolingual, bilingual, or multilingual. The languages displayed there are Indonesian, Javanese, English, Japanese, and Arabic. The first three languages are the dominant in any kind of signs collected from these sites. The presence of more than a language in sign has proved that the languages displayed tend to be complement to each other as they bear different information (and sometimes) functions. English is taken for its commerciality and prestige, Indonesian is employed for its communicative role, and Javanese is relied for its shared identity and closeness. This reflects the position of English as a global language, and it makes a concern about the position of local language in our public signs.
\end{abstract}

Keywords: commercial; linguistic landscape; marketing.

Linguistic landscape, since it was coined by Landry and Bourhis in 1997, has initiated a new study pattern which really attracted considerable attention of many researchers. Lots of exploration over the public texts have been conducted by viewing from various perspectives and theories, particularly from sociolinguistics, linguistics, and semiotics (Landry and Bourhis, 1997; Scollon and Scollon-Wong, 2003; Gorter, 2006; Gorter and Chenos, 2017; Manan et. al., 2014; Shang and Gou, 2017). Thus, the discipline is like an offer of new data type that can be analyzed using the existing theories. It makes an interdisciplinary approach according 
to the interest of each scholar.

In line with Gorter (2006), linguistic landscape is a study of signs in public spaces, looking at language displayed on store windows, business signs, posters, government notices, traffic signs, and so on. It focuses on any visible manifestation of written language (Gorter and Chenos, 2017). Landry and Bourhis (1997) have provided some information about their data, which includes texts written in public road signs, street names, advertising billboards, commercial shop signs, place names, and public signs on government buildings, which combine to form the linguistic landscape of a given territory, region, or urban identity.

The sign's language is linked to identification and cultural globalization (Gorter, 2006). Studies in the sector have revealed the significance of English as an international language. It has been a lingua franca for people from many origins to communicate and even share information. It is a popular marketing tool. English in our landscape today marks out some kind of international community. This one makes it appear in every business or commercial item. The space like this would be never empty; it is bound up with assets, history, and moral authority. People have always had a fundamental view that language has the power to sell; it contains a powerful magic to convince consumers to choose their product and services. Throughout this study, the researcher wants to reveal the usual urban views, landscape from a linguistic point of view and to reveal the correlation dynamics of "language use and space in urban areas" (Pennycook \& Otsuji, 2014).

In Purwokerto, the space like that is can be seen along two streets, Jalan Suharso and Jalan Overste Isdiman. Those area make a mix stretch around there, a place of commercial districts.. The existence of commercial establishments on the street cannot be separated from those who use the media to sell their products to prospective buyers. The function was created to entice potential buyers to visit their locations by utilizing a certain marketing strategy. The strategy is defined as "a structured function and the process of designing, introducing, presenting, and delivering a message and value to customers in order to pique their attention, thereby benefiting the organization" (Rajan, 2009).

Studies on linguistic landscapes in similar environment have been done by some researchers (Pamuji \& Khristianto, 2018; Firdausiyah, 2019; Lestari, 2019; Manan et al., 2014; Shang and Gou, 2017). The first three focusing on the sites in Indonesia, meanwhile the other two have their exploration in Malaysia and Singapore. Most of the studies make use of commercial sites as their locus. Shang and Gou (2017) took the shop signs, just like Lestari (2019) who has gone deeper by shooting out the spaces in a mall. Meanwhile, Pamuji and Khristianto (2018) specify their data on culinary shops in a commercial complex, by collecting data from the passerby perspective. Despite of a big gap between their settings, a similar result seems to be conclusive that English is the dominant code in such an area, emphasizing that it is the best language for selling products. It also highlights the notion that "pragmatic and affective adequacies" are the most important points (Shang and Gou, 2017).

The study in a specific context was reflected from Firdausiyah (2019), with a setting in an Islamic Boarding House in which the students learn Islamic teachings. She identified three languages were used in the signboards there: English, Arabic, and Indonesia. Again, the emergence of English is far different from the previous. Here it has a role to expose the students over English as an international language, or it has an educational purpose. A similar finding was also identified in Manan et al. (2014), whose setting was an outdoor public area. They found that the signs displayed fail to reflect the multiethnicity in the city, in spite the government has put a policy to strengthen the multicultural identity. One of the reasons is a pragmatism, in addition 
to identity/religion, which is similar to the previous. Once again, a similar message comes up - a domination of a language leads to a submission of others, concealing the minors behind the public view.

This study is to reveal the use of languages in the public sites where they play an important role in marketing their commodities. It is also to understand the reasons behind their selection.

\section{Method}

This study used a mixed method, incorporating quantitative and qualitative data. The first step was to identify the dominant language in the signs. The second step was to use words to describe the essential data (Creswell, 2003). The data of the language use in the public space were collected form two business streets in Purwokerto, Jalan Suharso and Overste Isdiman. According to Scollon and Scollon-Wong (2003), the language on signs in public spaces is in accordance with the language spoken by the community (geopolitical location), but some employ languages that are unrelated to the locality (socio- cultural association).

This was done in Purwokerto, a developing town in the southwest part of Central Java province, Indonesia. Geographically, it is categorized as a highland area as it is located right at the foot of the largest mountain in the province. Although only limited to the district capital, Purwokerto has developed very fast. Thus, it has made many industries to be their fields of fortune, making commercial spots in the town. As parts of their effort to sell their commodities, they make use of various promotions, among of which are the printed adds displayed along the area. For this reason, these two sites were chosen as the sample.

The poster, banners, and billboards were shot, using phone camera. The files of pictures were then put in a folder of a computer. There were closely observed to see the languages and their numbers in each signpost. Besides, it is also to identify the function of each language in them. In addition, the observation was a lead to check the functional relation between languages used in a display (multilingual sign).

\section{Results and Discussion}

This study conducted of observing the linguistic landsape Gor Satria and Overste Isdiman in Purwokerto. The researcher found the used of languages in advertising data chosen for sample areas. There are 60 signs collected as a data. They are located along the streets, within and around the public and commercial places. They were taken by shooting them in their original places. As a commercial complex, the two sites have some different characteristics in Purwokerto.

The data was examined for the presence of languages in the textual data. Throughout this stage, the number of languages used to categorize the sign pattern is as follows: monolanguage, bilingualism, or multilingualism. All signs are classified by the languages used there. The languages indicated in the public displays are Indonesian, English, Javanese, Arabic, Japanese, and Chinese.

Table 1. Signs in the commercial sites

\begin{tabular}{llllll}
\hline \multirow{2}{*}{ Group } & Languages & \multicolumn{3}{l}{ Location } \\
\cline { 3 - 6 } & & \multicolumn{3}{l}{ Site 1} & \multicolumn{2}{l}{ Site 2} \\
\cline { 3 - 6 } & & N. & $\%$ & N. & $\%$ \\
\hline Mono- & Indonesia & 13 & $21 \%$ & 8 & $13 \%$ \\
lingual- & Javanese & 1 & $2 \%$ & 1 & $2 \%$ \\
& English & 2 & $4 \%$ & 4 & $6 \%$ \\
\hline Bilin- & Indo-Javanese & 4 & $6 \%$ & 1 & $2 \%$ \\
gualism & Indo-English & 6 & $8 \%$ & 11 & $20 \%$ \\
& Indo-Chinese & 1 & $2 \%$ & - & - \\
& Javanese-English & 1 & $2 \%$ & - & - \\
\hline Multi- & English-Japanese & 1 & $2 \%$ & - & - \\
lingual- & Indo-Java- & - & - & 3 & $5 \%$ \\
ism 6 & nese-English & & & & \\
& Indo-En- & - & - & 1 & $2 \%$ \\
& glish-Japanese & & & & \\
& Indo-Java- & - & - & 1 & $2 \%$ \\
& nese-Arabic & & & & \\
\hline Total & Indo-Suraba- & - & - & 1 & $2 \%$ \\
& ya-English & & & & \\
\hline
\end{tabular}




\section{Monolingual Signs}

The first type of signs identified in the sites is a monolingual sign. The use of Indonesian (monolingual) must be extended in order to have high values and also be able to stand up with its strength since Indonesian is indeed the main language. Bagna and Barni (2009) The employment of only one language in a sign can also demonstrate that the language has prestige and the ability to stand alone. From the past to the present, Indonesian has been the official or sole language used in every field, including school, office, entertainment, and social media, as well as signage at restaurants, on roads, and even in government circles. The linguistic landscape of a certain territory, region, or urban agglomeration is formed by the language of public road signs, advertising billboards, street names, place names, commercial shop signs, and public signs on government buildings (Landry and Bourhis, 1997). Figure 1 shows the example of Indonesian sign.

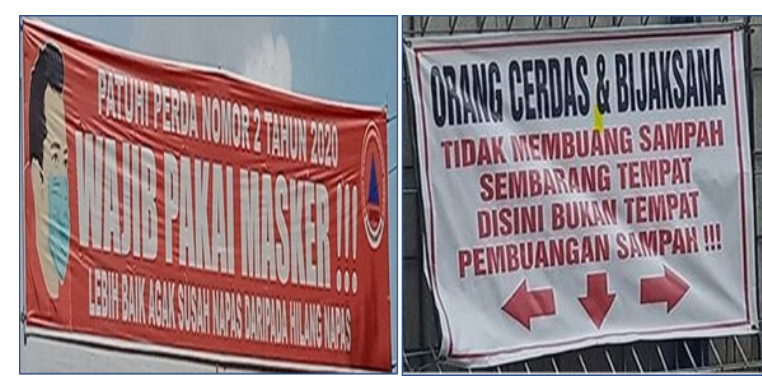

Figure 1. Indonesian Signs in the Sites

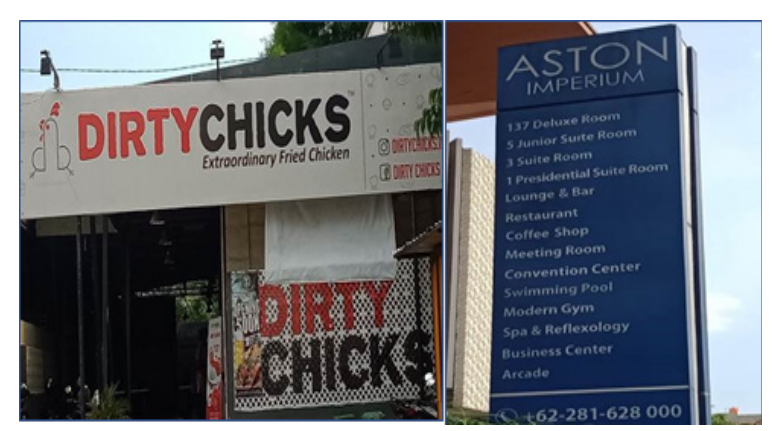

Figure 2. English in Monolingual Signs

Indonesia has become a main language used in Purwokerto's school, office and also media. In these sites, it is used the government buildings, a store, a restaurant, a sign on public sites and a street vendor. Surely, bahasa Indonesia is the most frequently used by the community in the areas, particularly in its written format. This makes the highest fluency of its use and it has made easier for the copy writer to create their persuasive attempts. Besides, they also believe its use will cover more audience as their target market cover non-Javanese people for whom using local language in the public display will not make a proper choice.

Purwokerto is located in Central Java within near Mount Slamet which has many interesting public destinations. There are some interesting sites near the town. The cool mountainy areas with natural and genuine exotics are excellent choices for the visitors. In addition, some cultural uniqueness is also parts of the magnet for the world. There are many domestic and foreign tourists who visit the town. By taking English in their ads, the industries expect to create a friendly atmosphere for the foreigners. Thus, they can easily introduce their products to them. These two sites in this inquiry are culinary areas which is very close to some top hotels in the town. Hence, it is very potential for the outlets to interest the visitors for overseas as they go downtown to test different meals.

The studies in verbal landscape have demonstrated the significance of English as the international language. Instead of English being widely regarded as the language of status, modernity, and refinement, it is most commonly found in ads and commercial sectors (Bolton, 2012; Cenoz \& Gorter 2008; Cenoz \& Gorter, 2009; Lawrence, 2012). Furthermore, the use of English in daily activities and in advertising indicates a desire to reach a larger global market and more consumers in order to sell their products or services and increase economic profits. Cenoz and Gorter (2009) the use of different languages in the sign reflects power, status and economic importance of 
them.

In our case, the use of English reflects more its power, globality, and prestige. Related to the potential consumers who are youths and/or middle-up economic status, English will draw their attention more easily. Naming a product in English will also elevate its value. Taking an example from the hotel display there, "swimming pool" sounds cooler than its Indonesian counterpart. Besides, some English terms in hotel industry are not very easy to have their similar prestigious Indonesian terms, like "lounge \& bar" - which are much more unattainable in local language. This is also the case with "Dirty Chicks" as a brand, which may translate into "Ayam Kotor" (Indonesian) or "Pitik Glopot" (local Javanese) - the readers will agree that the first is just an ultimate option, though "chicks" is not really grammatical. Thus, English in the industry does have its special power to lift up the values of the products.

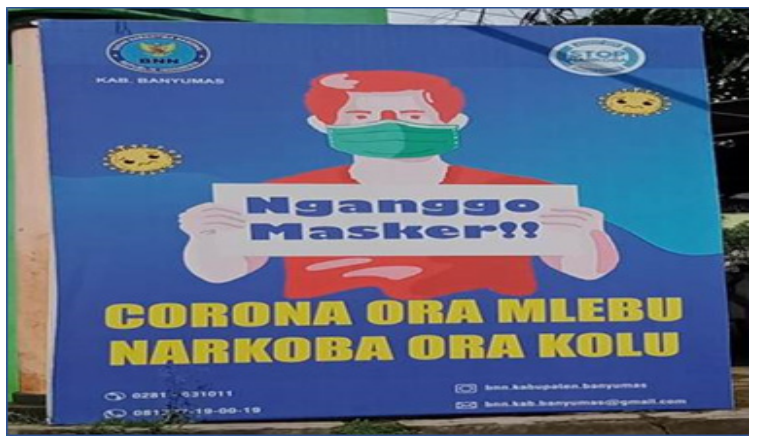

Figure 3. Javanese sign

Javanese is another language found there, though it is quite few. It is a language used by the most part of the community in the town. It is a language of association, which is used to interact between individuals and allows communication and transfer of information (Ahira, 2010). It makes an identity for the people there, known as Jawa Ngapak, or a peripheral variant of Javanese.

Javanese is the language used as a language of daily interaction in Java, especially Central Java. This is not surprising, because the glory of court life in the past was mostly found in Central Java than in other areas of Java. Javanese as the mother tongue is the language of daily interaction among Javanese people. Thus, the sign (Figure 3 ) is a display targeted to the Banyumas people-or others speaking Javanese. It is a public health campaign to remind the people of putting on their facial masks as they go out. Besides, it also warns the people about the danger of drugs and narcotics, especially for young, represented by a young man in the notice. This addition message is associated to the agency displaying the sign, a local national narcotic agency (BNN).

Based on the appearance of three languages in monolingual signs, it can be summed up that they were considered to be "normal language" for public communication. It means that they are supposed to communicate the message to their target. Otherwise, they will be complemented by another. Indonesian and Javanese are easily understandable to take this position, as we believe that the two are readable for the public in the town in general. In contrary, English cannot be put in a similar way. Its use in product description is really specific as the one in Figure 2, meaning it is agreeable for the target market. Its appearance in the brands and taglines do complies to the marketing rule-making up the commodity value $h$ free. It surely does not need much cost to use English in the marketing. Yet, English brand is believed to result in a certain positive value, meaning the value indeed scales up. In sum, to this point these languages are the dominance in our small town - at least from the sample area taken in this study.

\section{Bilingual Sign}

The second type of language use in the signs is bilingual. Seen from its number, this is the second dominant group after the monolingual. Language components in these signposts are pairs of Indonesian-English, Indonesian-Javanese, and Javanese-English. Discussing the presence of more than a language in a sign leads to the Huebner's classification (2009). It divides signs, based 
on how languages function to each other whether they are duplicating, fragmenting, or complementary. It refers to the information contained in a language whether it is the same, somewhat the same, or totally different from another/others.
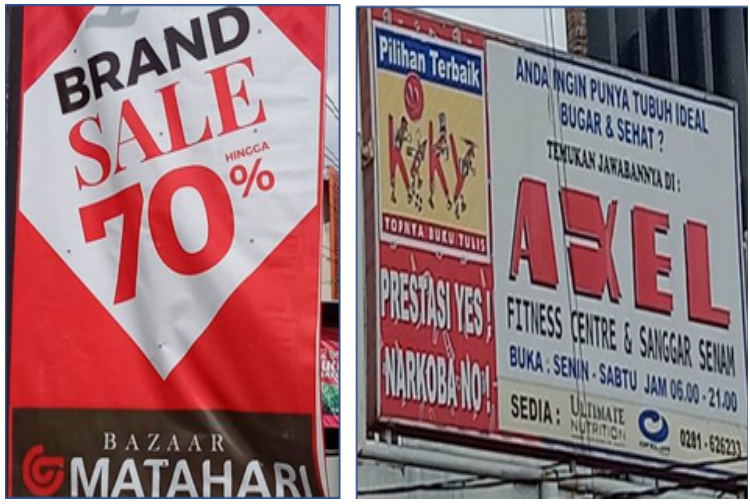

Figure 4. Indonesian-English Signs

Seen in Figure 4, IndonesianEnglish use in bottom-up signs. IndonesianEnglish is mostly used in name of shops, store, advertising, and restaurants. Lawrence (2012:88) as quoted by Fakhiroh and Rohmah (2018), argues that English has some positive associative meaning like modernity, success, refinement, and youthful. English is seen as a language with a modern association. The usage of English in the placard may entice people to visit. Indonesian-English signs are employed in the ads of fashion products and the service of fitness and gymnastics center.

From the Huebner's view (2009), the languages in the sign (Figure 4) are complementary in which each language communicate dfferent piece on information. In the first, English is tottaly adopted as the ads language, and Indonesian just refers to the brand, Matahari and the tricky one, made very small showing the discount limit, hingga. The English ads on sale use common and popular terms for Indonesian, especially the young as the main target for the sign. Thus, it is quite effective for the promotion. In the second sign, English is only used for the service promoted, fitness center which has its common equivalence, "pusat kebugaran". English is only a complement to the whole information, which are represented in Bahasa Indonesia. The word of the product name, Axel, is quite blurry, as it seems to mix English term and Indonesia graphology. It may derive from the world, "excellent". "Axel" is sometimes taken as person name, it can be a kid belonging to the owner-a common practice among Indonesian enternpreneur to use their kids' names for their brand.

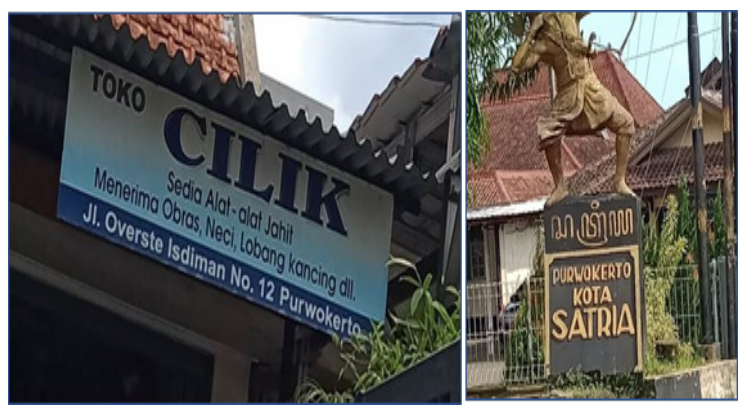

Figure 5. Indonesian-Javanese Sign

Another pair in bilingual signs is Indonesian-Javanese. Again, the languages here are complementary. The ads is in Bahasa Indonesia, and Javanese is taken only as the brand. Though, it is only a word there, but Javanese is made very salient. It makes an identity for the business. In another sign, Javanese is overlapping with bahasa Indonesia. It is not really bilingual, but more bi-scriptal or double graphs in which the name of Purwokerto is written in Latin and Javanese script. This small handling does make a significant identity for the monument. It is located very close to the town sport center. Thus, it makes a good impression for the visitors from other cities, especially non-Javanese travellers.

The last pair identified in bilingual display is Javanese-English. Javanese here is the language the ad adopts. English is just marginal; it is only a bait to attract the people passing the road, "Stop". Surely, it is a common English word for Indonesian people; it always appears in road sign, preventing people from crossing a particular area/lane. Besides, it also 


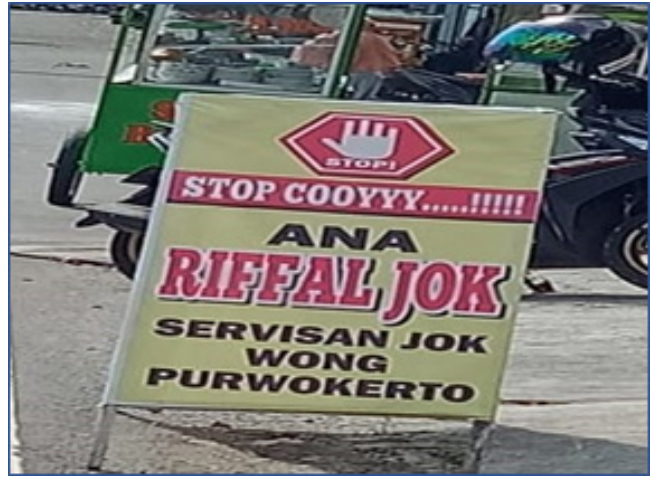

Figure 6. Javanese-English Signs

borrows English structure for the nomina group in the brand. Such a pattern is common in Indonesian outlets for many products, like mobile items, Internet and computer products, housing complex, and many others. We have brands like Murni Cel/Cellular, Utama Net, Prima Com, Damai Residence.

Javanese ads is very rare in the sites, or in the town in general. Reading the ads brings a friendly remark; it draws the people to be very close to the product owner. It sounds like a friend talking directly to us, as in a daily communication. Thus, it makes use of a shared identity to the potential customers as an approach to market the product. This can be seen in the text, as saying Wong Purwokerto (Purwokerto resident). Perhaps, it is a unique function of Javanese in the ads, which is properly modified to create such a persuasive power.

\section{Multilingual Sign}

The last type of the signs in the sites is multilingual sign, the use of more than two language in a sign. The foreign languges seen in these signs are English, Japanese, and Arabic. The multi-presence of English has raised issues of identity and power, which can have an impact on the balance of different languages in multilingual circumstances (Pennycook, 1994; Phillipson, 2003). The signs use some words having nothing to do with the place or the language spoken by the community. They are promotional signsof which visibility in public space, with an appealing design and the prestige of foreign languages, will definitely attract people.

Figure 7 shows two signs involving three languages. The first has English as the brand, Japanese Food, and Japanese is to inform the menus, then the introductory info is in Bahasa Indonesia. As it also serves Indonesian food, some menus are written in Bahasa Indonesia. Again, these languages are complementary to each other; each evokes different information. The use of Japanese in the signs are inevitable as they are the names of the foods, which can be said to be impossible to translate. Besides, the dishes have been popular for Indonesian young generation. English is taken as a brand for its commerciality, besides the terms have been very common among Indonesian people.

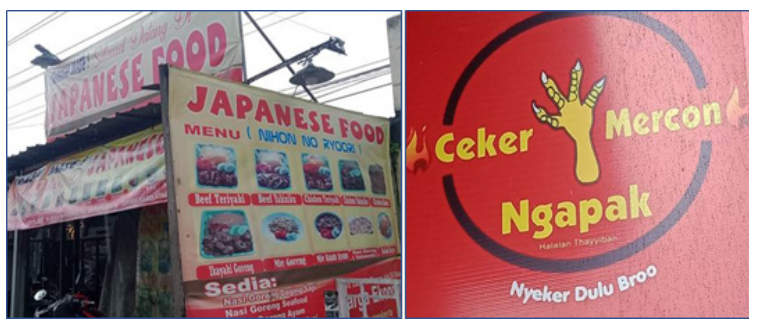

Figure 7. Multilingual Signs

The second sign shows a casual combination of languages, Javanese, Indonesian, English, and Arabic. These four make up a fine complementarity. Javanese is taken as the brand, it is the dominant one. The tagline consists of Indonesian and English, and the Arabic is to certify the edible quality for moslem customers. Thus, each language also takes a different function in the ads. The English word, "Bro", has a conative function to address the potential customers; the address is an intimate call among the close friends. The ads attempts to position the customers, particulary the young, to be very close to them. It makes a friendly address for the target market. 
Based on the signs with more than a language, it supports the previous evidence that the dominant languages in the ads in town are Indonesian, English, and Javanese. These languages are found in any kind of signs. The emergence of other than the three languages is marginal. They are taken because they tend to be fixed terms which are hard to translate into Bahasa Indonesia or Javanese. The nature of complementarity between the languages in a sign proves that Indonesian people prefer to mix the languages in their communication. The appearance of English is due to its commerciality, Bahasa Indonesia is taken for its communicative value, and Javanese is represented in the public sign for its exotism and its intimate and shared identity for the community.

\section{Conclusion}

Based on the discussion in the sections before, it can be concluded that signs in the surveyed sites are monolingual, bilingual, and multilingual. The signs using more than a language indicate that the languages there are always complementary; each language bears its own information, different from others. There are eight different languages appearing there, those are English, Indonesian, Javanese, English-Indonesian, IndonesianJavanese, English-Indonesian-Japanese, English-Indonesian-Japanese, IndonesianJavanese-English, Indonesian-JavaneseEnglish, Indonesian-Javanese-English, and Indonesian-Javanese-Arabic. The dominant languages in the ads are Indonesian and English. This reflects the position of English as a global language, and it makes a concern about the position of local language in our public signs.

\section{References}

Andriyanti, E. (2019). Linguistic landscape at Yogyakarta's senior high schools in multilingual context: Patterns and representation. Indonesian Journal of Applied Linguistics, 9, 85-97.doi: 10.17509/ijal.v9i1.13841.

Backhaus, P. (2007). Linguistic Landscapes. A Comparative Study of Urban Multilingualism in Tokyo. Clevedon: Multilingual Matters Ltd.

Blommaert, J. (2013). Ethnography, superdiversity and linguistic landscapes: Chronicles of complexity. Bristol: Multilingual Matters.

Cenoz, J. \& D. Gorter (2006). 'Linguistic Landscape and Minority Languages, International Journal of Multilingualism. Vol 3:1 No 67-80.

Creswell, John W. (2007). Research Design: Qualitative, Quantitative, and Mixed Methods Approaches (2nded). California: Sage Publications.

Firdausiyah, Hurrotul. 2019. Linguistic Landscape Study in Pondok Pesantren Putri Mambaus Sholihin Gresik. English Department, Faculty of Arts and Humanities. State Islamic University of Sunan Ampel Surabaya.

Gorter, D. (2006). Further Possibilities for Linguistic Landscape Research. In Gorter, D. (Ed.). Linguistic Landscape: A New Approach to Multilingualism. Clevedon, UK: Multilingual Matters, 81-89. Pdf.

Gorter, D. (2017). Linguistic Landscape and Trends in the Study of Schoolscapes. Linguistic and Education. Elsevier Inc.

Huebner, T. (2009). A framework for the linguistic analysis of linguistic landscapes. In E. Shohamy \& D. Gorter (Eds.), Linguistic landscape: Expanding the scenery (pp. 70-87). New York, NY:

Lestari, Dea Dwi (2019). A Study of Linguistic Landscape in Medan. http://repository.umsu.ac.id/ 
bitstream/123456789/84/1/A\%20

Study\%20Of\%20Lin guistic\%20 Landscape\%20In\%20Medan.pdf.

Manan, Syed Abdul, Maya Khemlani David, Francisco Perlas Dumanigb \& Khan Naqeebullah (2014). Politics, economics and identity: mapping the linguistic landscape of Kuala Lumpur, Malaysia. International Journal of Multilingualism: Routledge.

Pamuji, Eko and Khristianto. 2018. A Linguistic Landscape in Purwokerto: Power and Solidarity Stand Strong in a Culinary Center. Leksika Vol.12 No.1: 26-29.

Pennycook, A. \& Otsuji, E. (2014). Metrolingualism: Language in the city. London/New York: Routledge.

Rafsanjani, Adithiya. (2018). A Linguistic Landscape Study of Advertising Signs on Shopping Mall and Traditional Market in Surabaya. English Department Faculty of Letters and Humanity. The State Islamic University of Sunan Ampel Surabaya.

Routledge. Landry, R., \& Bourhis, R.Y. (1997). Linguistic landscape and ethnolinguistic vitality: An empirical study. Journal of Language and Social Psychology, 16(1), 2349. doi: 10.1177/0261927X970161002.

Scollon, R., \& Scollon, W. (2003). Disourse in Place: Language in Material World. New York:Routledge.

Shang, Guowen and Libo Guo. (2017). Linguistic landscape in Singapore: what shop names reveal about Singapore's multilingualism. International Journal of Multilingualism, 14:2, 183-201, DOI: 10.1080/14790718.2016.1218497.

Varadarajan, Rajan. (2009). Strategic Marketing and Marketing Strategy: Domain, Definition, Fundamental Issues and Fundamental Premises. Academy of Marketing Science. 